\title{
Analysis of the Transaction Cost in Modern Conditions
}

\author{
Elina A. Gurianova ${ }^{1}$, Igor N. Gurianov ${ }^{2,3}$ \& Svetlana A. Mechtcheriakova ${ }^{2,3}$ \\ ${ }^{1}$ Department of General Management, Kazan Federal University, Kazan, Russian Federation \\ ${ }^{2}$ Securities department, OAO “Tatneftekhiminvest-holding”, Kazan, Russian Federation \\ ${ }^{3}$ Department of General Management, Kazan Federal University, Kazan, Russian Federation \\ Correspondence: Elina A. Gurianova, Department of General Management, Kazan Federal University, Kazan, \\ Russian Federation. E-mail: elinagur@mail.ru
}

Received: June 19, 2014 Accepted: July 25, 2014 Online Published: September 28, 2014

doi:10.5539/ass.v10n20p67

URL: http://dx.doi.org/10.5539/ass.v10n20p67

\begin{abstract}
The activities of any organization linked to transaction costs, which are often of great size. If the organization will be able to lower transaction costs while maintaining performance, this can result in more effective organizational management structure and activities of the organization as a whole. Transaction costs arise because of different interests of the communicating parties, but also because of the uncertainty factor. Because transaction costs was escorted somehow all the functioning of the organization, you must implement their accounting and analysis. This will help to understand the causes of transaction costs and reduce them. But when ones transaction costs are decrease another transaction costs can increase. In order to reduce transaction costs, the need to consider options for the management structure, which would enable the organization to achieve their goals? The various organizational structures of governance have a different structure of transaction costs and a different size of transaction costs. Not to use the methodology transaction cost analysis can lead to unreasonable use of the resources of the organization. Analysis of the transaction cost is not possible without clear classification. In this article, this classification is presented. Transaction costs can be considered as the cost of the resources spent on the transaction. This allows you to calculate the size of transaction costs in the size in a cost equivalent. By use of the methodology which was proposed in this article, were examined the organizations that are located in Russian Federation and works in the petrochemical industry.
\end{abstract}

Keywords: ransaction costs, instability of the economy, the management efficiency, organizational structure of management

\section{Introduction}

In an unstable world economy, the economic agents often have unpredictable situations and problems that require quick responses, often leading to a loss. This means increased transaction costs at all levels of the economy: macroeconomic and microeconomic. The instability of the world economy has also led to the need for reform and restructuring of the institutional environment, at result is increasing transaction costs.

In an unstable world economy, to improve the effectiveness of the organization, management must make it our task to define the structure, dynamics and the sources of growth in transaction costs. The lack of the necessary tools for the analysis of transaction costs may lead to inefficient use of available resources, at the level of the individual firm and State and inter-State level. At the same time, methodically grounded approach to the analysis of transaction costs will allow not only to maintain, improve and use with maximum efficiency resource potential of the organization, but also the global economy as a whole.

Research on the essence and nature of transaction costs are devoted to the works of Coase R. (Coase, 1937), Commons J.R. (Commons, 1934), Arrow K. (Arrow, 1969), Stigler G. (Stigler, 1961), Jones G.R. and Hill C.W.L. (Jones, 1988), Nicholson W. (Nicholson, 1992), Chueng S. (Chueng, 1992).

Study of the theory of transaction cost on the classics of foreign economics Alchian A. and Demsetz H. (Alchian, 1972), Jensen M. C., Meckling W. H. (Jensen, 1979), Barzel У. (Barzel, 1982).

Transaction cost approaches to classification developed in the works Williamson O. E. (Williamson, 1985), Milgrom P. and Roberts J. (Milgrom, 1992), Menard C. and Shirley M. (Menard, 2008), Furubotn E. G. and Richter R. (Furubotn, 2005), North D. C. (North, 1987) and Eggertsson T. (Eggertsson, 1990). 
The concept of transaction costs was introduced by Coase R. in 30-ies in its article "The Nature of the Firm" (Coase, 1937). It was used to explain the existence of opposite market hierarchical structures, as a company. The specifics of functioning of firm he saw in suppressing the price mechanism and replace it with a system of internal administrative control.

In the modern economic theory, transaction costs have received numerous interpretations, sometimes diametrically opposed. So the Arrow K. (Arrow, 1969) defines transaction costs as the costs of operation of the economic system. Arrow K. compared the action of transaction costs in the economy with the effect of friction in physics. In the interpretation of North D. (North, 1987) transaction costs "are costs estimation of object properties and costs of enforcement and compliance". These costs are a source of social, political and economic institutions (Ajupov, 2014).

The majority of studies are either purely theoretical or implemented on the example of Macroeconomics of individual States. Transaction costs include any loss arising due to the inefficiencies of the joint action plans, concluded agreements and structures; inefficient responses to changed conditions; ineffective protection agreements (Alpatova, 2014). In a Word, they include all that in one way or another affect the relative efficiency of different methods of resource allocation and productive activities.

The market transaction costs are described in detail in the literature. However, not only the market but also the internal relations are impossible without the expenses of time and means for their implementation. Such costs can also be classified as transaction costs. They also arise from the process of economic interactions, although within the company, such costs are not always associated with the change of ownership of resources. However, the question of the internal transaction costs is currently insufficiently developed.

\section{Methodology}

Transaction costs accompanying the activities of any organization and are often very significant. If the company will be able to reduce data costs without compromising the achievement of organizational goals, this would enhance the effectiveness of the organizational structure of the management as a whole. To do this, you need to analyze transaction costs borne by the organization. This analysis requires the selection and classification of costs.

Transaction costs can have an equivalent value if we consider these costs as a value, the value of resources (financial, labor, time, etc.). This view of transaction costs to calculate their size.

\subsection{Classification of Transaction Costs}

For ease of identification and analysis of we have to do classification of transaction costs. In this article in order to analyze transaction costs of the company were separated into external and internal transaction costs.

\subsection{The External Transaction Costs}

The external transaction costs include:

1) Search costs and processing of external information (pricing, markets, and suppliers).

If we want to calculate the size of the transaction costs of search and processing of internal and external information, it will be necessary to make the analysis of losses which the firm will incur in the future in case will be made in management decision with incomplete information. In this case, the losses are not only direct losses but also the size of the lost benefits. It is possible to express such costs in monetary terms, comparing all the alternatives with the results. This category can also include the costs for the operation of the management information system. In the process of creating information databases, the organization spends the money for staff salaries, software, purchase and operation of equipment, controls and communication, which are the building blocks used by information technology.

2) The costs of negotiating and contracting (conclusion and registration of contracts).

The costs of negotiation involved loss of time directly in the negotiations, seeking or acquiring the necessary information for the negotiations. Costs for the contract relate to the cost of time and money on harmonization and amendment of the text of the contract conditions. These transaction costs also include attorney's fees and travel expenses.

3) Costs to avoid opportunistic behavior (losses and costs on the protection against unlawful acts on the part of contractors and public authorities).

Costs to avoid opportunistic behaviors linked to the difficulties of monitoring the conduct of parties of the contract. They include both the loss of opportunistic behavior, and costs of prevention. For this type of charge, 
you can also include the cost of forcing the other side to implement the terms of the contract.

\subsection{Internal Transaction Costs}

The internal transaction costs include:

1) Costs of collection, storage, and analysis of internal information (plans, identifying resources).

Costs of collection, storage, and analysis of inside information are similar to the cost of the search and processing of external information. The only difference is in object of study, as well as in the complexity and cost of obtaining reliable information. However, it would be a delusion to believe that information on internal communication channels is always timely and accurate. Within the organization, problems may arise as in transit, do data processing.

2) The costs of coordination (coordination of questions, meetings, influence expenses).

The organization incurs significant transaction costs of coordination among the various departments. These costs are mainly related to the need for: meetings; briefings; transfer of information on measures taken by the authorities; exceptions to avoid opportunistic demeanor on the part of employees and departments. These costs are supplemented influence costs. The various decisions taken in the organization, could affect not only its employees, but also other influential groups, such as shareholders, creditors, suppliers, consumers, etc. These groups can influence on made decisions by way of manipulation of information, use of personal connections, and way by provide pressure. All this is related to transaction costs, reducing organizational effectiveness. Cost analysis of listed above transactional expenses is complicated by the fact that some of them are quite difficult to identify and quantify.

3) Control costs (including the costs to avoid opportunistic behaviors in the internal environment of the organization).

Costs of control are directly linked to the ability to avoid opportunistic behavior. Opportunistic behavior problem comes from human nature, the desire of man to realize their own interests that may conflict with the interests of the company (Ismagilova, 2014). Opportunistic behavior manifests itself in the deception, non-compliance with its commitments, etc. The probability of opportunistic behavior arises from difficulties associated with accurate assessment of the efforts made by the employee in the performance of an activity. Costs to avoid opportunistic behaviors include the related losses in efficiency and costs necessary to eliminate or restrict such conduct.

\section{Results}

The methodology proposed above were analyzed the organization related to the petrochemical industry of the Russian Federation. As a result, the following were established chart showing trends over the past five years. Results of the analysis are presented in Figure 1.

Analysis of the data allows the following conclusions to be drawn.

For petrochemical enterprises of the Russian Federation that the internal transaction costs higher than external. This is due to the fact that these organizations have large dimensions partly because of its structure are included in a single chain. Association small disparate organizations in major consolidation moves part of external costs into the internal transaction costs.

In large petrochemical organizations are high costs of control, as they tend to increase with an increase in the size of your organization when you lose a direct link between the work and its results. In large organizations, also raises the problem of coordination units and the collection, storage and analysis of internal information.

In 2008, according to the charts, we can see a relatively high amount of external transaction costs, which tend to decrease in subsequent years compared with the internal transaction costs. This is due to the economic crisis of 2008. In the economy of the Russian Federation there have been growth trends after the 2009. The economic crisis has caused the need to collect additional information and market analysis to develop measures to address its impact on the activities of the organization. The total height of the external transaction costs influenced the growth of accounts receivable. That in turn has led to an increase costs off opportunistic behavior. 


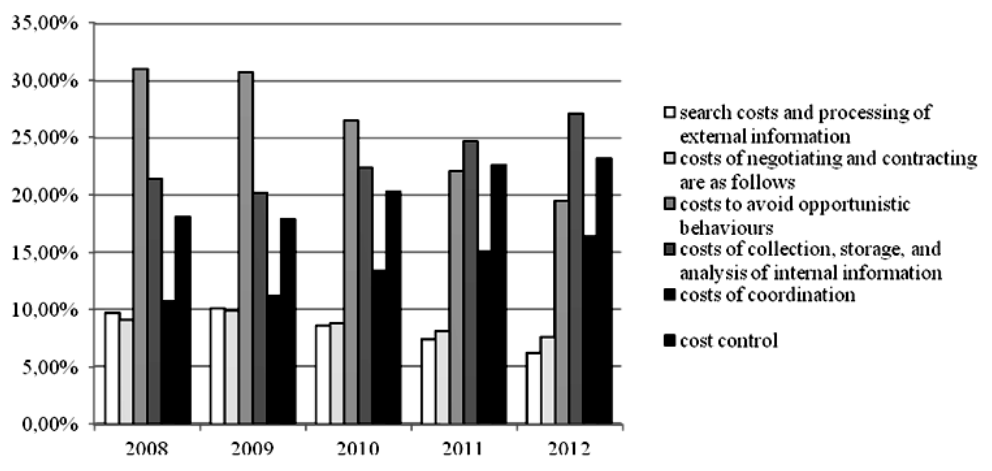

Figure 1. The structure of the transaction costs of petrochemical industry of the Russian Federation in 2008-2012 Source: Based on data from the petrochemical industry organizations for 2008-2012 years

\section{Discussion}

A sharp increase in transaction costs in a volatile economy, due to the complex process of drafting the contracts because of the complexity of predicting events. In such circumstances, the higher the probability of opportunistic behavior between the contracting parties (Kramin, 2014). More complex and expensive process of finding information and developing forecasts even in the short term.

External economic instability could not fail to have an impact on the internal activity of the organization. For example, to best suit the environment organizations have to make changes in the organizational structure (Makarov, 2014). Any organizational changes have led to increased transaction costs due to the need to adapt the organization to the new conditions. Errors are inevitable in such circumstances, additional coordination, collecting of additional information, as well as the likelihood of opportunistic behavior by employees, inspired by a desire to gain new privileges, opportunities in new conditions (Milgrom, 1990).

In the preparation of the two groups of transactions costs: external and internal. The fact that the instability of the economy with a view to reducing the high transaction costs some companies can do decision on merge among themselves to reduce dependence on the external environment (Poltoradneva, 2014). This is to some extent reduces the external transaction costs, but, in turn, increase the internal.

To reduce transaction costs in the face of instability in the world economy, it must be understood that the centralization of control increases the speed of decision making, reducing transaction costs and increasing the speed of response of the organization to the changes in the external environment (Safiullin, 2014). Reducing transaction costs may facilitate change of formal and informal norms, both internally and at the State level. Create a favorable legal environment of enterprises will reduce transaction costs by reducing the number of acts of opportunistic behavior by the contracting parties.

In terms of external instability greatly reduce transaction costs of search information will enable the development of the information infrastructure of the economy (Wallis, 1986). To reduce internal costs for searching and processing information to improve the quality of information system, qualified, motivated staff, as well as reduce the number of parts involved in the decision-making process.

\section{Conclusion}

Transaction costs have the property of interchangeability. This means that in some cases, reduce the external transaction costs, leads to an increase in internal transaction costs and vice versa.

To explore possibilities for reducing transaction costs to analyze the various options for the organizational structure to achieve goals and corresponding to them transaction costs. When the transactions, it should be remembered that this can lead not only to reduce costs but also to the loss of profitability and vice versa. In this case, you can rely on the following rule: the growth of transaction costs, overlap of profit growth, and their decline should not entail a deterioration of financial performance.

But in an unstable world economy, we must not forget that in order to achieve economic recovery requires action not only at the level of individual organizations. Economic policies should be oriented towards creating social and sustainable economy, taking into account national circumstances. Only such a model allows you to secure the future of both the Russian and the world economy. 


\section{References}

Ajupov, A., \& Polteva, T. (2014). Handling depositary receipts for global financial markets. Life Science Journal, $11(6 \mathrm{~s}), 464-468$.

Alchian, A. A., \& Demsetz, H. (1975). Production, Information Costs, And Economic Organization. American Economic Review, 62, 777-795.

Alpatova, E., Makarov, A., Maksutina, E., \& Nazmeev, E. (2014). Modern labor market in Russia and its regulation. Life science Journal, 11(6s), 350-353.

Arrow, K. (1969). The Organization of Economic Activity: Issues Pertinent to the Choice of Market versus Non-market Allocation the Analysis and Evaluation of Public Expenditure. The PPB System, 1, 48.

Barzel, Y. (1982). Measurement costs and the organization of markets. Journal of Law and Economics, 25(1), 27-48. http://dx.doi.org/10.1086/467005

Chueng, S. (1992). On the New Institutional Economics. Contract Economics (p. 52). Oxford, UK: B. Blackwell.

Coase, R. (1937). The Nature of the Firm. Economica, 4(16), 386-405. http://dx.doi.org/10.1111/j.1468-0335. 1937.tb00002.x

Commons, J. (1931). Institutional Economics. American Economic Review, 21, 648-657.

Demsetz, H. (1990). The Organization of Economic Activity. Oxford, UK: Basil Blackwell Scientific Publications.

Eggertsson, T. (1990). Economic Behavior and Institutions. Principles of Neoinstitutional Economics, 1, 385. http://dx.doi.org/10.1017/CBO9780511609404

Furubotn, E. G., \& Richter, R. (2005). Institutions and economic theory the contribution of the new institutional economics (2nd ed.). Ann Arbor: University of Michigan Press.

Ismagilova, G., Safiullin, L., \& Bagautdinova, N. (2014). Tourism development in region based on historical heritage. Life Science, 11(6s), 363-367.

Jensen, M., \& Meckling, W. (1979). Rights and production functions: An application to labor-managed firms and codetermination. Journal of Business, 52(4), 469-506. http://dx.doi.org/10.1086/296060

Jones, G., \& Hill, C. (1988). Transaction Costs Analysis of Strategy Structure Choice. Strategic Management Journal, 9, 159-172. http://dx.doi.org/10.1002/smj.4250090206

Kramin, M., Safiullin, L., Kramin, T., \& Timiryasova, A. (2014). Drivers of economic growth and investment attractiveness of Russian regions. Life Science, 11(6s), 526-530.

Makarov, A., Nazmeev, E., Maksutina, E., \& Alpatova, E. (2014). Education reform in context of innovative development of the Russian economy. Life Science, 11(6s), 372-375.

Menard, C., \& Shirley, M. (2008). Handbook of New Institutional Economics (p. 890). Boston-New York-Berlin-Dordrecht: Springer. http://dx.doi.org/10.1007/978-3-540-69305-5

Milgrom, P., \& Roberts, J. (1990). Bargaining costs, influence costs, and the organization of economic activity. Cambridge: Cambridge University Press.

Milgrom, P., \& Roberts, J. (1992). Economics, Organization and Management (pp. 93-117). Prentice Hall.

Nicholson, W. (1992). Microeconoinic Theory: Basic Principles and Extensions (5th ed.). The Dryden Press.

North, D. (1987). Institutions, transaction costs, and economic growth. Economic Inquiry, 25(3). http://dx.doi.org/10.1111/j.1465-7295.1987.tb00750.x

Poltoradneva, N. (2014). Terminological basis of financial engineering: Comparative analysis of the definitions "financial product" and "financial instrument". Life Science Journal, 11(6s), 490-493.

Safiullin, L., Gafurov, I., Shaidullin, R., \& Safiullin, N. (2014). Socio-economic development of the region and its historical and cultural heritage. Life science, 11(6s), 400-404.

Safiullin, L., Novenkova, A., Safiullin, N., \& Ismagilova, G. (2014). Prospects of small business in Tatarstan. Life Science Journal, 11(6s), 396-399.

Stigler, G. (1961). The Economics of Information. Journal of Political Economy, 69(3), 213-225. http://dx.doi.org/10.1086/258464 
The Organization of Economic Activity: Issues Pertinent to the Choice of Market versus Non-market Allocation. (n. d.). UC Santa Barbara Economics. Retrieved May 10, 2014, from http://www.econ.ucsb.edu/ tedb/ Courses/UCSBpf/readings/ArrowNonMktActivity1969.pdf

Wallis, J., \& North, D. (1986). Measuring the transaction sector in the American economy, 1870-1970. In S. Engerman, \& R. Gallman (Eds.), Long-Term Factorsin American Economic Growth (pp. 95-148). University of Chicago Press, Chicago and London.

Williamson, O. (1985). Reflections on the new institutional economics. Journal of Institutional and Theoretical Economics, 141(1).

\section{Copyrights}

Copyright for this article is retained by the author(s), with first publication rights granted to the journal.

This is an open-access article distributed under the terms and conditions of the Creative Commons Attribution license (http://creativecommons.org/licenses/by/3.0/). 